\title{
Short- and long-term variability of spectral solar UV irradiance at Thessaloniki, Greece: effects of changes in aerosols, total ozone and clouds
}

\author{
Ilias Fountoulakis ${ }^{1}$, Alkiviadis F. Bais ${ }^{1}$, Konstantinos Fragkos ${ }^{1}$, Charickleia Meleti ${ }^{1}$, Kleareti Tourpali ${ }^{1}$, and \\ Melina Maria Zempila ${ }^{1, a}$ \\ ${ }^{1}$ Aristotle University of Thessaloniki, Laboratory of Atmospheric Physics, Thessaloniki, Greece \\ ${ }^{a}$ now at: Natural Resource Ecology Laboratory, Colorado State University, Fort Collins, USA
}

Correspondence to: Ilias Fountoulakis (iliasnf@auth.gr)

Received: 24 November 2015 - Published in Atmos. Chem. Phys. Discuss.: 18 December 2015

Revised: 18 February 2016 - Accepted: 19 February 2016 - Published: 1 March 2016

\begin{abstract}
In this study, we discuss the short- and the longterm variability of spectral UV irradiance at Thessaloniki, Greece, using a long, quality-controlled data set from two Brewer spectrophotometers. Long-term changes in spectral UV irradiance at $307.5,324$ and $350 \mathrm{~nm}$ for the period 1994 2014 are presented for different solar zenith angles and discussed in association with changes in total ozone column (TOC), aerosol optical depth (AOD) and cloudiness observed in the same period. Positive changes in annual mean anomalies of UV irradiance, ranging from 2 to $6 \%$ per decade, have been detected both for clear- and all-sky conditions. The changes are generally greater for larger solar zenith angles and for shorter wavelengths. For clear-skies, these changes are, in most cases, statistically significant at the $95 \%$ confidence limit. Decreases in the aerosol load and weakening of the attenuation by clouds lead to increases in UV irradiance in the summer, of 7-9\% per decade for $64^{\circ}$ solar zenith angle. The increasing TOC in winter counteracts the effect of decreasing AOD for this particular season, leading to small, statistically insignificant, negative long-term changes in irradiance at $307.5 \mathrm{~nm}$. Annual mean UV irradiance levels are increasing from 1994 to 2006 and remain relatively stable thereafter, possibly due to the combined changes in the amount and optical properties of aerosols. However, no statistically significant corresponding turning point has been detected in the long-term changes of AOD. The absence of signatures of changes in AOD in the short-term variability of irradiance in the UV-A may have been caused by changes in the single scattering albedo of aerosols, which may counteract the effects of changes in AOD on irradiance. The anti-
\end{abstract}

correlation between the year-to-year variability of the irradiance at $307.5 \mathrm{~nm}$ and TOC is clear and becomes clearer as the AOD decreases.

\section{Introduction}

Although ultraviolet (UV) radiation is only a small fraction $(<10 \%)$ of the total solar radiation that reaches the Earth's surface, it is vital for the life on Earth (Asta et al., 2011; Häder et al., 2015; Lucas et al., 2015; Madronich et al., 2015; UNEP, 2010; Williamson et al., 2014). The amount of solar UV radiation reaching the atmosphere is changing periodically due to changes in the Earth-Sun distance and the solar activity. Solar radiation with wavelengths shorter than $290 \mathrm{~nm}$ is entirely blocked by the atmosphere, while for longer wavelengths the fraction that penetrates to the surface depends mainly on the solar zenith angle, the composition of the atmosphere and the characteristics of the surface (Kerr and Fioletov, 2008). The interaction between the UV radiation, the atmospheric constituents and the characteristics of the surface is complicated and not yet fully understood (Bernhard et al., 2007; Kerr and Fioletov, 2008; Meinander et al., 2009). The geophysical parameters that mainly affect the levels of the surface UV irradiance are: ozone, clouds, surface reflectivity and aerosols (Arola et al., 2003; Bais et al., 1993; Bernhard et al., 2007; WMO, 2007).

From the early 1980s until the mid-1990s, the sharp decline of the stratospheric ozone over the mid- and high latitudes led to important increases in the surface UV irradi- 
ance (Kerr and McElroy, 1993; Madronich et al., 1998). The successful implementation of the Montreal protocol decelerated the weakening of the ozone layer (Egorova et al., 2013; Mäder et al., 2010; Newman and McKenzie, 2011) and many recent studies indicate the first signs of recovery over the Northern Hemisphere (Kuttippurath et al., 2013; McLinden and Fioletov, 2011; Newchurch et al., 2003; Smedley et al., 2012). Signs from the onset of ozone recovery since the late 1990s on surface UV-B irradiance have been mainly detected over the northern high latitudes; recent studies indicate that UV-B has been declining during the last 2 decades (Bernhard, 2011; Eleftheratos et al., 2014). However, during the same period, both the UV-B and the UV-A irradiance are increasing over many locations in the Northern Hemisphere mid-latitudes, mainly due to the negative trends in the amount of clouds and aerosols (De Bock et al., 2014; Fitzka et al., 2012; Román et al., 2015; Smedley et al., 2012; Zerefos et al., 2012). In a recent study, Fragkos et al. (2015) showed that in Thessaloniki, even under extreme high (low) total ozone column (TOC) conditions, the erythemal irradiance can be lower (higher) than its climatological values due to the dominant effect of aerosols. Zerefos et al. (2012) suggest that over Canada, Europe and Japan there is a statistically significant evidence of a slowdown or even a turning point in the upward UV-B trends after 2006, which is an indication that since then the negative trends of aerosols are no more the main driver of the long-term changes in UV-B irradiance.

In the next decades, ozone, aerosols, clouds and surface reflectivity are projected to undergo important changes (IPCC, 2013). Changes in these factors may alter the levels of the surface UV irradiance (Bais et al., 2015, 2011; Hegglin and Shepherd, 2009; Tourpali et al., 2009; Watanabe et al., 2011) with important impacts on human health and the balance of the ecosystems (UNEP, 2010; Williamson et al., 2014). However, the uncertainties in the spatial and temporal variability, the magnitude and the direction of the projected changes of surface UV irradiance are still high (Bais et al., 2015). Thus, good quality measurements of the spectral UV irradiance and the main factors controlling its levels at the Earth's surface are of great importance for achieving better understanding and more accurate modelling of the interactions among UV radiation, ozone, aerosols, clouds and surface reflectivity (García et al., 2015; Kreuter et al., 2014; Mayer and Kylling, 2005; Schwander et al., 1997).

Accurate knowledge of the levels of spectral surface UV irradiance is necessary in order to quantify effects on the health of humans (Kazantzidis et al., 2015; Webb et al., 2010) and ecosystems (Ballare et al., 2011; Häder et al., 2011), and prevent potential impacts from over- or under-exposure to UV radiation (Lucas et al., 2015). Additionally, reliable estimations of the trends of spectral surface UV irradiance provide useful information for assessing these impacts and for adopting proper measures (Morgenstern et al., 2008; Newman and McKenzie, 2011; van Dijk et al., 2013). Climatolo- gies and trends of surface UV irradiance (spectral or broadband) can be derived either directly from ground-based measurements (Fitzka et al., 2012; Glandorf et al., 2005; Zerefos, 2002), or indirectly from measurements of surface reflectivity, ozone, aerosols and cloudiness derived either from satellites (Damiani et al., 2014; Fioletov et al., 2004; Li et al., 2000), or from ground-based instruments (Antón et al., 2011; Román et al., 2015; Walker, 2009). The uncertainties of these parameters and the applied methodologies increase the uncertainty of the indirectly derived UV irradiance, when compared to measurements (Cordero et al., 2013; Weihs and Webb, 1997). Thus, long records of good quality measurements of UV irradiance lead to more reliable estimations of its short-term and long-term changes (Arola et al., 2003; Weatherhead et al., 1998).

The present study aims at the quantification of the longterm changes in surface UV irradiance using spectral measurements which have been recorded since 1990 at Thessaloniki (Bais et al., 2001; Garane et al., 2006; Gröbner et al., 2006), one of the longest time series globally (Glandorf et al., 2005). An important aspect is also the attribution of the trends and variability of UV irradiance to changes in the TOC, the aerosol optical depth (AOD) and cloudiness during the same period. Special emphasis is given to the reported slowdown of the positive trends of UV irradiance (Zerefos et al., 2012) and their correlation with the reported aerosol decline over the Northern Hemisphere (Turnock et al., 2015).

\section{Instrumentation and data}

In the 1980s, increased concern about stratospheric ozone depletion (Farman et al., 1985; Solomon et al., 1986) and its effect on the levels of UV radiation at the Earth's surface (Kerr and McElroy, 1993; Madronich et al., 1995; Zerefos, 2002) led to increased deployment of ground-based instruments worldwide (Fioletov et al., 1999), to monitor the TOC and the surface UV irradiance. Among these instruments, several Brewer spectrophotometers (Brewer, 1973; Kerr et al., 1985) were deployed at different locations including Thessaloniki, Greece, where the first commercially available singlemonochromator Brewer with serial number 005 (B005) was installed in 1982. Since then B005 has performed continuous measurements of the TOC and the columnar $\mathrm{SO}_{2}$ (Bais et al., 1993, 1985; Meleti et al., 2012; Zerefos, 1984). These measurements are also used to derive the aerosol optical depth at specific UV-B wavelengths (Kazadzis et al., 2007). Monitoring of spectral UV irradiance with B005 started in 1990 (Bais et al., 1996, 1993; Garane et al., 2006). Since 1993, a second, double-monochromator, Brewer spectrophotometer with serial number 086 (B086) has also operated at Thessaloniki for continuous monitoring of the spectral UV irradiance (Bais et al., 1996). Both instruments are located at the facilities of the Laboratory of Atmospheric Physics (latitude $40.634^{\circ} \mathrm{N}$, longitude $22.956^{\circ} \mathrm{E}$, altitude $60 \mathrm{~m}$ above sea level). 
The spectral measurements of B005 cover the wavelength range $290-325 \mathrm{~nm}$ in steps of $0.5 \mathrm{~nm}$ and spectral resolution of about $0.55 \mathrm{~nm}$ (FWHM). The corresponding spectral range for B086 is $290-363 \mathrm{~nm}$, with the same wavelength step and very similar spectral resolution. The UV data set of both instruments was quality checked and re-evaluated up to the end of 2005 (Garane et al., 2006) and has been used in different studies (Kazadzis et al., 2009; Kazantzidis et al., 2006, 2009; Meleti et al., 2009). Garane et al. (2006) presented a comprehensive analysis of the uncertainties from all known sources that may affect the calibration procedures and the spectral measurements of B005 and B086. In this study the overall $1 \sigma$ uncertainty of the measured irradiance was estimated to $5 \%$ for B086 and from $6.5 \%$ near $305 \mathrm{~nm}$ to $5 \%$ near $320 \mathrm{~nm}$ for B005. Recently, the quality control and the re-evaluation of the post-2005 data set have been completed and the time series is now extended to the end of 2014, comprising about 170000 spectra for B005 and 140000 spectra for B086.

Direct spectral irradiance measurements performed with B005 at 306.3, 310.0, 313.5, 316.8 and $320.1 \mathrm{~nm}$ are used to derive the TOC (Kerr et al., 1981) and the AOD (Gröbner and Meleti, 2004; Meleti and Cappellani, 2000). The uncertainty of the TOC measurements is estimated to about $1 \%$ or less (Kerr et al., 1985), while for the AOD the uncertainty is of the order of 0.04 at $320 \mathrm{~nm}$ for air mass 1.4 (Kazadzis et al., 2007). Comparisons with AOD data for the period 2005-2014 provided from a collocated Cimel sunphotometer which is part of AERONET (http://aeronet.gsfc. nasa.gov/) revealed an overall agreement to within 0.1 for air mass values up to 3.2 .

For the trend analysis, which will be discussed later, data for the 11-year solar cycle and the Quasi-Biennial Oscillation (QBO) of the winds in the equatorial stratosphere have been used. Monthly means for the solar flux at $10.7 \mathrm{~cm}$ were downloaded from the NOAA national geophysical data centre (http://www.ngdc.noaa.gov/stp/space-weather/solar-data/ solar-features/solar-radio/noontime-flux/penticton/), while for the QBO wind data were downloaded from the Freie Universität Berlin (http://www.geo.fu-berlin.de/en/met/ag/ strat/produkte/qbo/index.html).

The spectral irradiances used in this study are averages of five measurements (within $\pm 1 \mathrm{~nm}$ about the nominal wavelength) and the analysis is performed for 307.5, 324 and $350 \mathrm{~nm}$. The irradiance for the former two wavelengths is derived from both instruments while for $350 \mathrm{~nm}$ it is derived only from B086. The solar irradiance at $307.5 \mathrm{~nm}$ is strongly absorbed by ozone in contrast to the other two wavelengths where the ozone absorption is either weak $(324 \mathrm{~nm})$ or negligible $(350 \mathrm{~nm})$. In many studies, the irradiance at $305 \mathrm{~nm}$ has been used to estimate the effect of TOC on UVB irradiance. However, for large solar zenith angles and/or under cloudy conditions the effects from the dark signal and the stray light are very important for such low wavelength, especially for the single-monochromator Brewers (Karppinen et al., 2014).
Therefore, in the present study the irradiance at $307.5 \mathrm{~nm}$ has been chosen because it is stronger than at $305 \mathrm{~nm}$, with significantly higher signal-to-noise ratio required for more accurate determination of trends, while the effect of ozone absorption remains very strong. Additionally, the changes in irradiance for $307.5 \mathrm{~nm}$ are more representative of the changes in the erythemal irradiance, which is an important, humanhealth-related metric. Finally, the effect of $\mathrm{SO}_{2}$ absorption in relation to the effect of ozone absorption at $307.5 \mathrm{~nm}$ is the weakest in the range $306-309 \mathrm{~nm}$. The changes in irradiance at $324 \mathrm{~nm}$ and $350 \mathrm{~nm}$ for clear-skies are mainly determined by the changes in the amount and optical properties of the aerosols. Thus the effect of TOC on the long-term trends can be estimated by comparing the trend in irradiance at $307.5 \mathrm{~nm}$ with the trend at these longer wavelengths. In order to detect the presence of clouds during measurements and separate the data under clear-skies, data from a collocated pyranometer (type Kipp \& Zonen CM-21) recorded at high temporal resolution (once per minute) have been used (Bais et al., 2013).

The long-term variability of the spectral UV irradiance was investigated for specific solar zenith angles, in order to minimize interferences from the different paths of radiation in the atmosphere. Specifically, averages of measurements corresponding to SZAs within $\pm 1^{\circ}$ about the nominal SZA were used. In order to eliminate remaining biases induced by these slightly different SZAs, correction factors were derived with the radiative transfer model UVSPEC, which is included in version 1.7 of the libRadtran package (Mayer and Kylling, 2005). The simulations were made for a range of TOC and AOD values within the expected range of variability over Thessaloniki: 250-550 DU for TOC and 0-1.4 for the AOD at $320 \mathrm{~nm}$, using the US standard atmospheric profile (Anderson et al., 1986), the aerosol profile suggested by Shettle (1989), and typical values of the surface reflectivity, the single scattering albedo (SSA) and the asymmetry factor of $0.05,0.85$ and 0.7 respectively (Bais et al., 2005). The simulations revealed that while for small SZAs and long wavelengths the differences in clear-sky UV irradiance are small, at $305 \mathrm{~nm}$ the differences escalate to $60 \%$ for a change in SZA from 69 to $71^{\circ}$. The following empirical relationship has been derived to correct the measured irradiance at SZAs different than the nominal:

$\frac{I_{0}}{I_{\theta}}=1+\alpha\left(\lambda, \theta_{0}\right) \cdot\left(\frac{1}{\cos \theta}-\frac{1}{\cos \theta_{0}}\right)$,

where $\theta_{0}$ is the nominal SZA, $\theta$ is the actual SZA, $I_{0}$ is the irradiance for $\theta_{0}, I_{\theta}$ is the irradiance for $\theta$ and $\alpha\left(\lambda, \theta_{0}\right)$ is the correction factor which depends on wavelength $\lambda$ and $\theta_{0}$. After applying the correction, the differences between irradiances for SZAs which differ by up to $2^{\circ}$ do not exceed $10 \%$ ( $\pm 5 \%$ about the mean) for wavelengths ranging from 290 to $400 \mathrm{~nm}$ and SZAs from 15 to $80^{\circ}$. For the wavelengths above $310 \mathrm{~nm}$ and SZAs smaller than $70^{\circ}$ the remaining discrepancies are generally below $2 \%$, while for the same SZAs 
and wavelengths between 305 and $310 \mathrm{~nm}$ the remaining discrepancies range between 1 and $5 \%$. Thus for $307.5 \mathrm{~nm}$, the remaining uncertainties due to differences from the nominal SZA range from 1 to $5 \%$ for SZAs between 30 and $70^{\circ}$. For the same range of SZAs the corresponding uncertainties are lower than 2 and $1 \%$ for 324 and $350 \mathrm{~nm}$, respectively.

The monthly mean values of the irradiance at $307.5 \mathrm{~nm}$ and at $324 \mathrm{~nm}$, the TOC, and the AOD derived from B005 since 1990 are presented in Fig. 1. The period from June 1991 until December 1993 has been shaded to highlight the low TOC values due to the Mt. Pinatubo volcanic eruption in June 1991 (Hofmann et al., 1994; Randel et al., 1995). The annual cycle of the irradiance at $307.5 \mathrm{~nm}$ is clearly anticorrelated with the annual cycle of TOC while for the irradiance at $324 \mathrm{~nm}$ the annual variability is mainly caused by changes in cloudiness. There is an indication of increasing tendency in irradiance, for both wavelengths since the beginning of the record, which will be further discussed in the following sections. The monthly mean TOC generally ranges between about 280 and $400 \mathrm{DU}$ with no obvious long-term trend. The high aerosol load over Thessaloniki is depicted in the monthly mean values of AOD that range between about 0.3 and 0.9. However, during the last two decades, the mean levels of the AOD are decreasing and its inter-annual variability becomes weaker. As will be shown in the following, changes in aerosols play a key role in both the short- and the long-term variability of the UV irradiance over Thessaloniki.

\section{Data analysis and results}

\subsection{Methodology}

The present study has two main objectives: first, to quantify and discuss the long- and short-term changes in UV irradiance, and second, to investigate whether a turning point exists in the long-term variability of the UV time series, during the period 1994-2014. Data before 1994 are not used in the analysis, to eliminate the effect on total ozone from the volcanic eruption of Mt Pinatubo in June 1991. Large amounts of aerosols, mainly sulfuric, were injected into the stratosphere which led to decreases in TOC in the period 19911993, as can be seen from Fig. 1. In addition, measurements of spectral UV irradiance at Thessaloniki before June 1991 are sparse and available for less than 2 years.

Assuming that part of the long-term variability of the clear-sky UV irradiance is due to ozone, one would expect that there should be two modes in this trend: one for the period of decreasing total ozone and one for the period of stabilized or increasing total ozone. For some Northern Hemisphere locations, it was found (Zerefos et al., 2012) that surface UV-B irradiance increases faster in the period before 2006. As shown in the following, such a turning point exists also in the 20-year-long UV data series of Thessaloniki. Although quantitative estimates of the trends for each of the
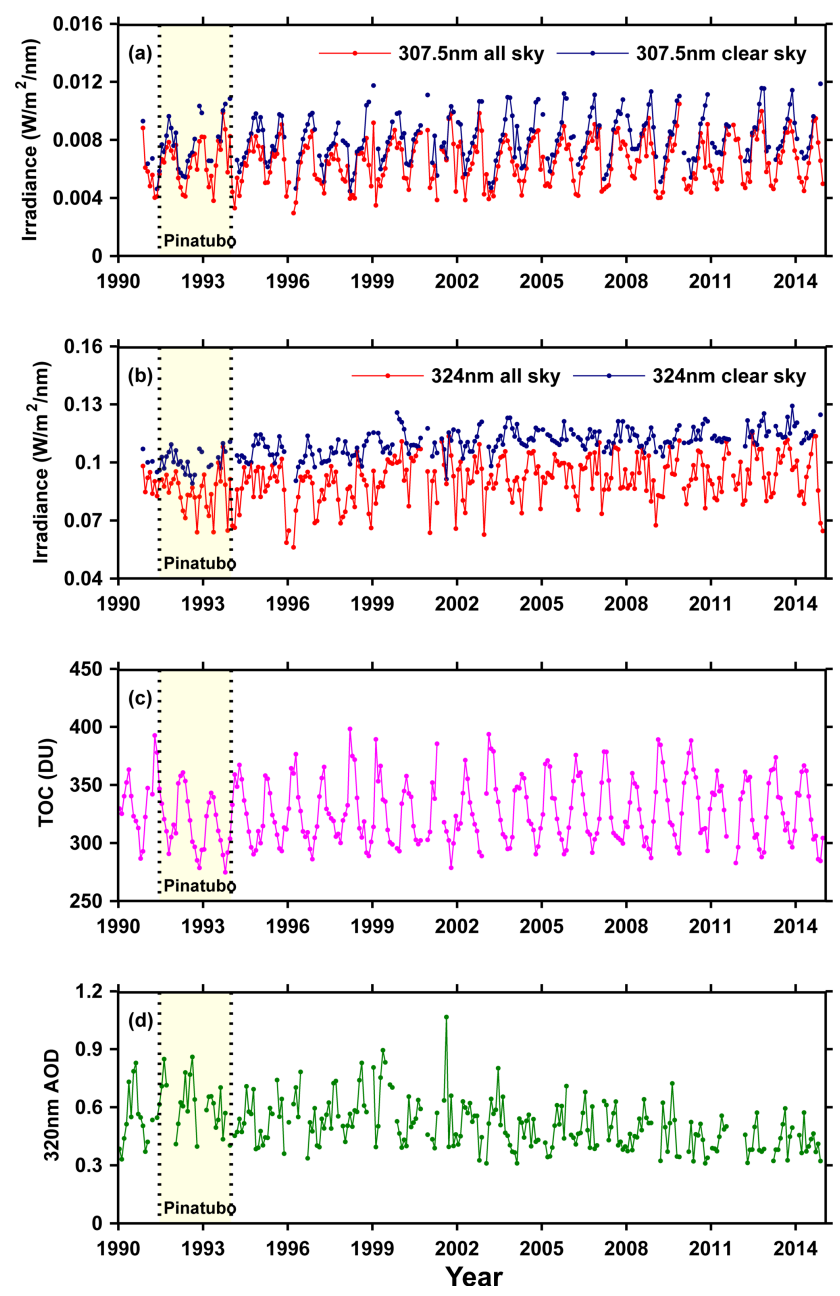

Figure 1. Time series of monthly mean all-sky and clear-sky irradiance at $63^{\circ}\left( \pm 1^{\circ}\right)$ SZA for (a) $307.5 \mathrm{~nm}$ and (b) $324 \mathrm{~nm}$. Monthly means derived from daily means are shown in (c) for TOC and (d) for AOD at $320 \mathrm{~nm}$. Monthly means were calculated only for months with at least 10 days of data.

two sub-periods have been derived they are discussed briefly and in a more qualitative way, since the two time periods are too short to consider the quantitative estimates of the trends reliable (Arola et al., 2003; Weatherhead et al., 1998). Thus, in the following analysis long-term trends are comprehensively discussed only for the entire period 1994-2014.

With respect to the presence of autocorrelation in the time series of TOC and UV and its effects on trend analysis, Weatherhead et al. (1998) have reported that the deseasonalized monthly mean UV irradiance data are autocorrelated in the first order. For the station of Thessaloniki, the autocorrelation of the all-sky data set is estimated to be small, less than 0.2 . In contrast, for the clear-sky data set the autocorrelation is larger, ranging between 0.3 and 0.5 for different SZAs, and may affect the significance of the derived trends. In our analysis the autocorrelation has not been removed either from 
the all-sky or the clear-sky data sets. As discussed in Yang et al. (2006) removing the autocorrelation from time series with large number of gaps, as in our case for the clear-sky UV data set, can induce artificial tendencies and biases in the derived trends. In order to accurately detect the turning point in the trends of the UV irradiance and to determine its statistical significance, the methodology of Yang et al. (2006) was applied on the monthly mean anomalies. This study aimed at detecting a turning point in a time series of TOC with a large number of gaps using a non-autoregressive model. The additional uncertainty due to the remaining autocorrelation was taken into account in the estimation of the statistical significance associated with the detection of the turning point.

For the analysis of long-term changes we calculated daily anomalies for TOC, AOD and spectral UV irradiance at different SZAs in order to remove the effect of SZA in the annual variability of irradiance. These daily anomalies were calculated by subtracting from each data point the climatological value for that day which was derived from the entire data set. Monthly mean anomalies were calculated by averaging the daily anomalies for months with at least 10 days of available data. As a next step, the effects of QBO and the 11-year solar cycle were filtered from both the TOC and UV irradiance data sets, by applying a multilinear regression analysis. The procedure described in, for example, Zerefos et al. (2012) was followed with the only difference being that in the present study we did not use an autoregressive model, due to gaps in the clear-sky UV data set. It was found that the difference in the linear trends derived for the period 19942014 with and without filtering the effects of these two natural cycles is generally smaller than $0.5 \%$ per decade, thus smaller than the $1 \sigma$ uncertainty of the trends which ranges from about 1 to $3 \%$ per decade. However, it is not always negligible compared to the magnitude of the derived trends which for all cases range between about -5 and $10 \%$ per decade.

The number of gaps in the time series of the UV irradiance is higher in the first half compared to the second half of the period of study. In order to suppress the effect of the uneven distribution of the measurements, the long-term changes in UV irradiance were calculated from the yearly mean anomalies, instead of those derived from the multilinear model. After removing the effects of the solar cycle and the QBO from the monthly mean anomalies, the data set was recomposed and the yearly mean anomalies were calculated. It was found again that the difference in the linear trends derived from the yearly mean anomalies and directly from the multilinear model is small, with the former being higher by only $0.1-$ $0.4 \%$ per decade. The statistical significance of the trends is derived from the Mann-Kendall test (Burkey, 2006). In the following, a trend is considered significant when it is statistically significant at the $95 \%$ confidence level.

\subsection{Comparison between the trends from the two Brewers for different SZAs}

Following the re-evaluation and quality control of the entire data set, the trends of the UV irradiance were calculated separately for the two Brewers operating at Thessaloniki. Mean ratios between quasi-synchronous (within $\pm 1 \mathrm{~min}$ ) spectral UV irradiance measurements from B005 and B086 under allsky conditions were calculated for different SZAs to evaluate the applied corrections. Instrumental characteristics of Brewers (e.g. the slit function) may differ for different instruments (e.g. Lakkala et al., 2008) leading to differences between, even synchronous, single-wavelength measurements. Comparing averages over small spectral intervals partly suppress these effects. In the present study averages for $5 \mathrm{~nm}$ spectral intervals were compared instead of irradiance measurements at single wavelengths (or averages for narrower spectral intervals), because they are wide enough to suppress a great part of the effect of these characteristics, while at the same time they are narrow enough to assess whether measurements are properly corrected for, for example, the effects of temperature and SZA with respect to wavelength. For the wavelength range $310-325 \mathrm{~nm}$ the ratios are very close to 1 with a standard deviation of about $5 \%$. For shorter wavelengths, the mean ratio gradually decreases and for the 300 $305 \mathrm{~nm}$ range it is $\sim 0.96$ with a standard deviation of about $10 \%$. As already discussed, the uncertainties and the deviations from unity arise from the different characteristics of the two instruments and from the imperfect synchronization of the measurements (Garane et al., 2006). No dependency of the ratio from the temperature or the solar zenith angle was found. The good agreement in the absolute levels of the measured irradiance by the two instruments is an indication of the quality of the re-evaluated data. It should be noted, however, that the synchronous measurements represent only $\sim 50 \%$ of the available data. The trends from both instruments for the entire period 1994-2014 were compared for different solar zenith angles from 30 to $70^{\circ}$ in steps of $10^{\circ}$. The results for 307.5 and $324 \mathrm{~nm}$ are presented in Fig. 2 both for clear-sky and all-sky conditions.

For $307.5 \mathrm{~nm}$, statistically significant trends were found for clear-skies for both instruments and all SZAs, and for all-skies in B005 for 30 and $70^{\circ}$ SZA. For $324 \mathrm{~nm}$, only the clear-sky trends from B005 and for 30 and $40^{\circ}$ SZA are statistically significant. The trends for $324 \mathrm{~nm}$ are generally smaller than those for $307.5 \mathrm{~nm}$. The results are quite satisfactory and consistent since for the same wavelengths and SZAs the irradiance trends from B005 and B086 do not differ by more than $2 \%$ per decade and in most cases they agree within $1 \sigma$. The derived trends both for clear- and all-sky data and for all SZAs are positive and range between 1 and $6 \%$ per decade. Although the dependence of the trends on the SZA appears to be small and within the uncertainty limits, at large SZAs the trends are greater. This dependence can be partially attributed to the increasing optical path of radiation 

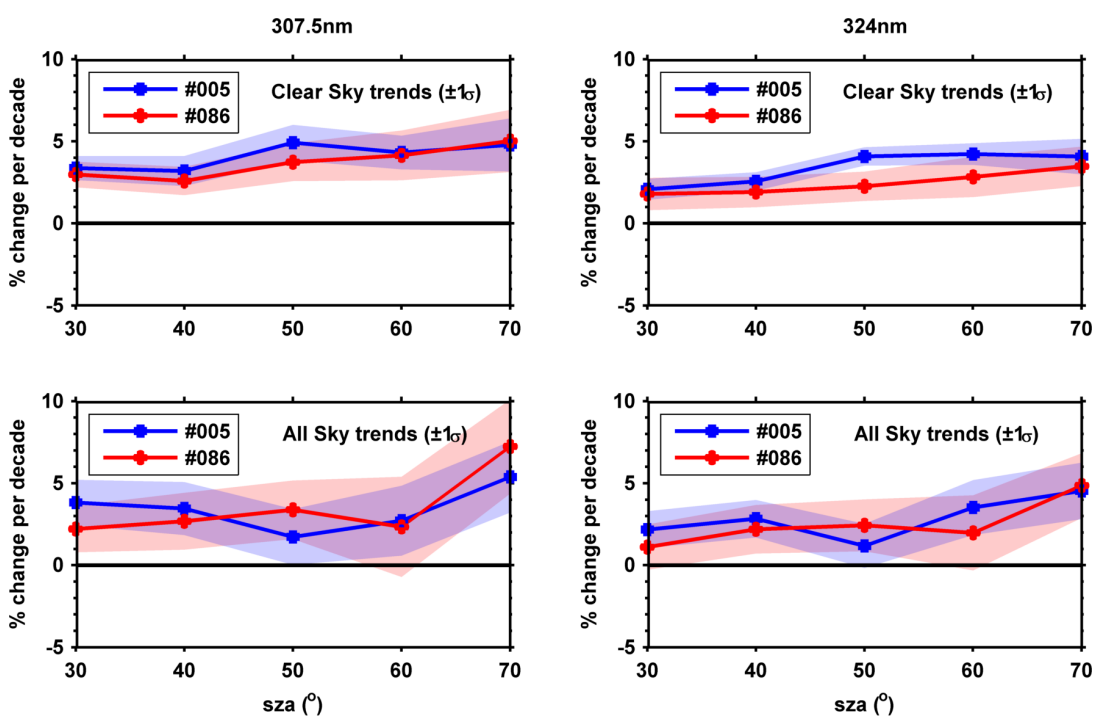

Figure 2. Linear trends (in \% per decade) of spectral UV irradiance at $307.5 \mathrm{~nm}$ (left) and $324 \mathrm{~nm}$ (right) for clear-sky (upper) and all-sky (lower) conditions derived from Brewers \#086 and \#005, as a function of solar zenith angle. The shaded areas represent the $\pm 1 \sigma$ uncertainty of the derived trends.

with SZA, which leads to stronger absorption from ozone or aerosols. However, for different SZAs, the data sets comprise data from different periods in the year (e.g. for $\mathrm{SZA}=30^{\circ}$ data exist only from April to August, while for $\mathrm{SZA}=70^{\circ}$ data are available during the entire year). Since the long-term changes of TOC, AOD and cloudiness are different for different seasons, the irradiance trends for different SZAs should be affected differently by these factors.

\subsection{Seasonal trends}

Since the results from both instruments are generally similar, only the data from B086 are used in the following, since this instrument has superior characteristics, at least with respect to the rejection of stray light and angular response. Seasonal trends of the spectral UV irradiance for 307.5, 324 and $350 \mathrm{~nm}$ (Fig. 3) were calculated and compared to the corresponding trends of the daily mean TOC and AOD (Fig. 4). The trends in AOD are statistically significant for all cases presented, in contrast to the trends in TOC which are not statistically significant. For SZAs larger than $63^{\circ}$ data are available during the whole year - thus, the irradiance for $64^{\circ} \mathrm{SZA}$ (data ranging from 63 to $65^{\circ}$ ) is used in the analysis of trends. The effect of the changes in cloudiness is assessed by comparing the trends of the clear-sky and the all-sky irradiance.

As expected, the seasonal trends for 324 and the $350 \mathrm{~nm}$ are similar for both, clear-sky and all-sky conditions. The changes of the solar irradiance at these wavelengths are practically unaffected by the changes of TOC, while they are mainly affected by the changes in aerosols and clouds. In general, the effects of changes in aerosol amount and/or properties on UV irradiance are stronger for shorter wavelengths. Thus, the important negative trends of the AOD at
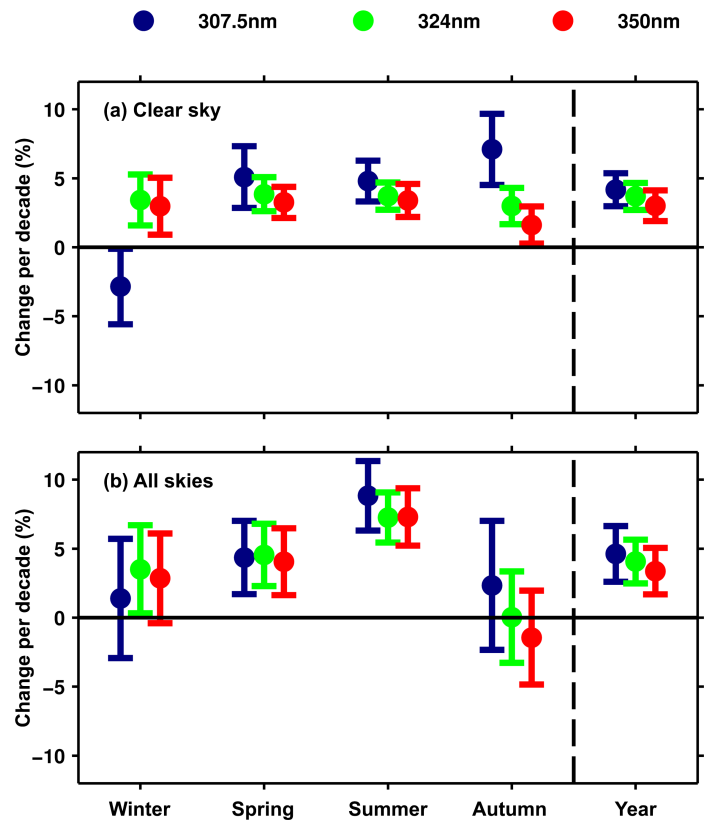

Figure 3. Long-term changes (in $\%$ per decade) and associated $1 \sigma$ uncertainty of the seasonal and the yearly mean spectral irradiance for $307.5,324$ and $350 \mathrm{~nm}$ at $64^{\circ} \mathrm{SZA}$, for clear-skies (a) and allskies (b) at Thessaloniki.

$320 \mathrm{~nm}$ that have been observed for Thessaloniki lead to slightly less positive trends for the irradiance at $350 \mathrm{~nm}$ than at $324 \mathrm{~nm}$. It must be clarified at this point that the interaction of solar UV radiation with aerosols is very complex and the changes in the AOD cannot explain the changes in UV irradiance without taking into account the absorption efficiency 


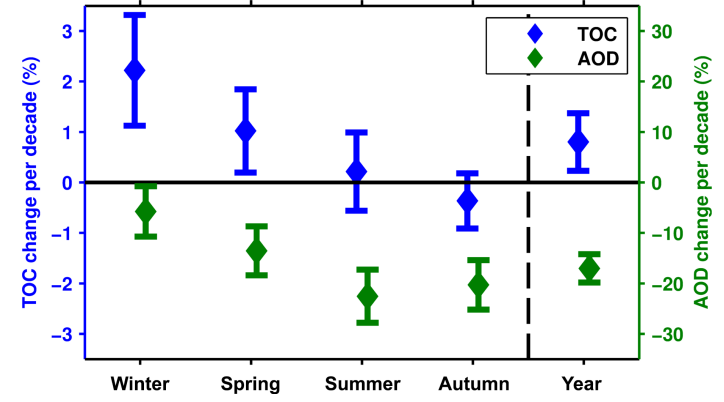

Figure 4. Long-term changes (in \% per decade) and the associated $1 \sigma$ uncertainty of the seasonal and the yearly mean of TOC (blue rhombs) and the AOD at $320 \mathrm{~nm}$ (green rhombs). The left (blue) axis corresponds to the changes in TOC while the right (green) axis to changes in AOD.

of the aerosols (i.e. the SSA) for which no measurements are available for this period. For example, decreases in the SSA (greater absorption efficiency) counteract the effect of decreases in the AOD. As will be discussed later, the fact that the changes in clear-sky UV-A irradiance ( 324 and $350 \mathrm{~nm}$ ) cannot be fully explained by the changes in the AOD is an indication that changes in other optical properties of aerosols, such as the SSA, may have occurred.

The greatest changes in irradiance at 324 and $350 \mathrm{~nm}$ were found in summer both for clear-sky and all-sky conditions. The trend for clear-skies at these wavelengths is about $3.5 \%$ per decade, while for $307.5 \mathrm{~nm}$ it increases to about $5 \%$ per decade. The main driver for the changes under clear-skies appears to be the decreasing AOD, which for summer is more than $20 \%$ per decade. For all-skies, the positive trends are almost double than those for clear-skies (about $7 \%$ for 324 and $350 \mathrm{~nm}$ and about $9 \%$ for $307.5 \mathrm{~nm}$ ), suggesting that the attenuation of irradiance by clouds is decreasing during the last 2 decades. All these trends are statistically significant. For winter, the trends in irradiance for 324 and $350 \mathrm{~nm}$ are 3.5 and $3.0 \%$ respectively both for clear-skies and all-skies, suggesting that cloud effects during the last two decades are very small in winter and changes in aerosols are the dominant factor. This conclusion is confirmed by the negative trend of the AOD shown in Fig. 4. For $307.5 \mathrm{~nm}$ the increases in TOC counteract the effects of changing aerosols, leading to a negative trend of about $-3 \%$ per decade for irradiance under clear-skies. However, none of the trends in winter is statistically significant.

For spring, the trends for clear-skies are similar to those in summer for all three wavelengths, while for all-skies trends are smaller; by $0.5-1 \%$. Thus, as for winter, the UV trends are due mainly to decreasing AOD. Although for that season the trend in TOC is about $1 \%$ per decade, this is not reflected in the trend of clear-sky irradiance at $307.5 \mathrm{~nm}$ which is slightly larger than in the UV-A wavelengths, instead of being smaller. For this season only the trend for $350 \mathrm{~nm}$ is statistically significant.
For autumn, the trends in clear-sky irradiance are approximately 7,3 and $1.5 \%$ for $307.5,324$ and $350 \mathrm{~nm}$ respectively, and statistically significant only for the first two wavelengths. For all-skies, the trends are 3-4\% lower, suggesting an increasing attenuation by clouds during this season. However, the differences between the clear-sky and the all-sky trends are within the uncertainty limits of the latter. The allsky trends for autumn are not statistically significant. One of the possible reasons for the stronger increase of the irradiance at $307.5 \mathrm{~nm}$ compared to 324 and $350 \mathrm{~nm}$ is the small negative trend in TOC. Additionally, the relatively large difference between the trends for 324 and $350 \mathrm{~nm}$ is explained by the decreasing aerosols which have much stronger impact on shorter than on longer wavelengths.

Finally, the yearly averaged TOC is slightly increasing, by about $0.8 \%$ per decade, but this change is not statistically significant. In contrast, the yearly mean AOD has been decreasing by about $17 \%$ per decade, and therefore AOD is the dominant driver of the changes in the yearly mean UV irradiance. The trends in UV irradiance range from 3 to $4 \%$ for clear-skies, while for all-skies they are about $0.5 \%$ larger. At shorter wavelengths the trends are larger, possibly due to the negative trend in TOC and the stronger effect of aerosols on the irradiance at these wavelengths.

The results presented in Fig. 3 lead to the conclusion that the enhanced attenuation of UV radiation by clouds in summer is balanced by the decreased attenuation in autumn, leading to a negligible effect on the yearly mean UV irradiance. However, as in all cases presented, the differences between the trends in clear-sky and all-sky irradiance for summer and autumn are similar to (or even lower than) their $1 \sigma$ uncertainty, which is a strong indication that the estimated changes in the attenuation of the UV irradiance by clouds are not significant.

\subsection{The role of ozone and aerosols on short- and long-term variability of irradiance}

In the following we discuss in more detail the short- and long-term variability of clear-sky UV irradiance at 307.5 and $350 \mathrm{~nm}$ in association with the evolution of factors causing this variability. The analysis of the variability is performed on annual mean anomalies of UV irradiance at $64^{\circ} \mathrm{SZA}$, TOC and AOD, as well as for mean anomalies for the periods December-May (winter-spring) and June-November (summer-autumn); the former being affected mainly by changes in ozone, and the latter by changes in aerosols. Furthermore, we explore a potential turning point in the time series of irradiance at Thessaloniki using monthly mean anomalies, in an attempt to confirm the findings of Zerefos et al. (2012).

The results for $324 \mathrm{~nm}$ are not discussed since they are similar to those for $350 \mathrm{~nm}$. For monthly mean anomalies for the entire year, a turning point in the upward trend of irradiance at both 307.5 and $350 \mathrm{~nm}$ has been detected in 2006, 
Table 1. Trends of TOC, AOD at $320 \mathrm{~nm}$ and spectral UV irradiance at 307.5 and $350 \mathrm{~nm}$, for different periods. Asterisks denote the statistically significant trends.

\begin{tabular}{llrrr}
\hline & Period & Winter-spring & Summer-autumn & Year \\
\hline $307.5 \mathrm{~nm}$ (change \% per decade) & $1994-2006$ & - & $11.0 \pm 3.3^{*}$ & $7.1 \pm 2.1^{*}$ \\
& $2006-2014$ & - & $-0.16 \pm 7.7$ & $-0.28 \pm 5.0$ \\
& $1994-2014$ & $2.2 \pm 1.9$ & $7.0 \pm 1.9^{*}$ & $4.5 \pm 1.2^{*}$ \\
\hline $350 \mathrm{~nm}$ (change \% per decade) & $1994-2006$ & $6.9 \pm 1.8^{*}$ & $6.7 \pm 1.6^{*}$ & $7.0 \pm 1.4^{*}$ \\
& $2006-2014$ & $-2.8 \pm 4.1$ & $-2.5 \pm 3.7$ & $-3.3 \pm 3.2$ \\
& $1994-2014$ & $3.8 \pm 1.0^{*}$ & $3.4 \pm 1.0^{*}$ & $3.3 \pm 0.9^{*}$ \\
\hline TOC (change \% per decade) & $1994-2014$ & $1.7 \pm 0.8^{*}$ & $0.0 \pm 0.6$ & $0.8 \pm 0.6$ \\
\hline $320 \mathrm{~nm}$ AOD (absolute change per decade) & $1994-2014$ & $-0.06 \pm 0.02^{*}$ & $-0.11 \pm 0.02^{*}$ & $-0.09 \pm 0.01^{*}$ \\
\hline
\end{tabular}

statistically significant at the $95 \%$ confidence level. Since the same pattern occurs at both wavelengths and since no statistically significant turning point has been detected for TOC, this piece-wise trend pattern in UV irradiance has likely been caused by changes in aerosols. However, the small negative trend in UV irradiance observed after 2006 (see Table 1 and Fig. 5) does not comply with the negative monotonic trend in AOD during the whole period of study which continues also after 2006. The behaviour of aerosols after 2006 has been verified by an independent data set from a collocated Cimel sun-photometer, which revealed a decreasing trend of about 0.1 per decade in AOD at $440 \mathrm{~nm}$ from 2006 to 2014, similar to that of B005. Thus, the only factor that could explain the small negative trend in UV irradiance during this period would be a negative trend in the SSA (Bais et al., 2005; Nikitidou et al., 2013). This assumption cannot be easily verified since the SSA data from the Cimel and from satellite overpasses (e.g. http://disc.sci.gsfc.nasa.gov/giovanni) are sparse and inadequate to derive reliable trends. However, simulations with UVSPEC revealed that for SZAs greater than $60^{\circ}$ and for typical aerosol properties and atmospheric conditions for Thessaloniki, the effect of a decrease in AOD at $320 \mathrm{~nm}$ by 0.1 can be reversed by a simultaneous decrease in SSA by less than 0.1 .

As shown in Table 1, the trends for $350 \mathrm{~nm}$ for winterspring, summer-autumn and the entire year are similar. For all the three cases the UV irradiance increases by about $10 \%$ from 1994 to 2006 and then it slightly decreases from 2006 to 2014 resulting to a mean rate of increase of about $3.5 \%$ per decade for the entire period 1994-2014. For the three cases the mean rate of decrease for the AOD is similar before and after 2006. Additionally, the year-to-year variability of the mean anomalies for the AOD is not clearly anti-correlated with the year-to-year variability of the mean anomalies for the UV irradiance at $350 \mathrm{~nm}$, which can be only attributed to changes in SSA. SSA may differ importantly for different types of aerosols (Takemura et al., 2002). The aerosol mixture over Thessaloniki consists of several different types of aerosols (e.g. urban, continental, marine, dust) and its com- position varies (Amiridis et al., 2005; Koukouli et al., 2006). This could lead to large variability of the SSA, even within the same day (e.g. Ialongo et al., 2010). An increase of the mean SSA in 1999 would, for example, explain why the very high annual mean levels of AOD in the specific year are not depicted in the levels of UV irradiance.

The changes of the UV irradiance at $307.5 \mathrm{~nm}$ are highly affected by changes in TOC and aerosols. For the winterspring period no statistically significant turning point has been detected in the trend for this wavelength. Additionally, the mean trend in irradiance for the period 1994-2014 is weak (Table 1) compared to the corresponding trend for the period June-November, and is likely caused by the combined, but opposing, effects of a statistically significant positive trend in TOC and a negative trend in AOD. For the period June-November no trend was detected in TOC, thus, as for $350 \mathrm{~nm}$, the UV irradiance at $307.5 \mathrm{~nm}$ increases steadily from 1994 to 2006 due to decreasing AOD and after 2006 remains unchanged. A pattern which is similar to that for the period June-November appears also in the annual means, with changes in irradiance dominated again by changes in aerosols of opposite sign.

Some interesting conclusions emerge from Fig. 5: by comparing Fig. 5a-c with $\mathrm{g}-\mathrm{i}$, one can notice an anti-correlation between the year-to-year variability of TOC and the yearto-year variability of UV irradiance at $307.5 \mathrm{~nm}$, which becomes stronger as the AOD decreases. For example, the low yearly mean TOC in 2000, 2008 and 2011, compared in each case with the yearly mean TOC for the nearest (e.g. 4 or 5) years, coincides with high UV irradiance at $307.5 \mathrm{~nm}$ while correspondingly the high TOC in 1998, 2010 and 2013 coincides with low UV irradiance at $307.5 \mathrm{~nm}$. Obviously, while the year-to-year variability in irradiance at $307.5 \mathrm{~nm}$ is mainly driven by the changes in TOC, its long-term changes are mainly driven by the changes in aerosols. For example, the yearly mean TOC in 2010 is the highest that has been recorded during the entire period 1994-2014 (Steinbrecht et al., 2011) and has led to low yearly mean irradiance at $307.5 \mathrm{~nm}$. However, the yearly mean irradiance at 

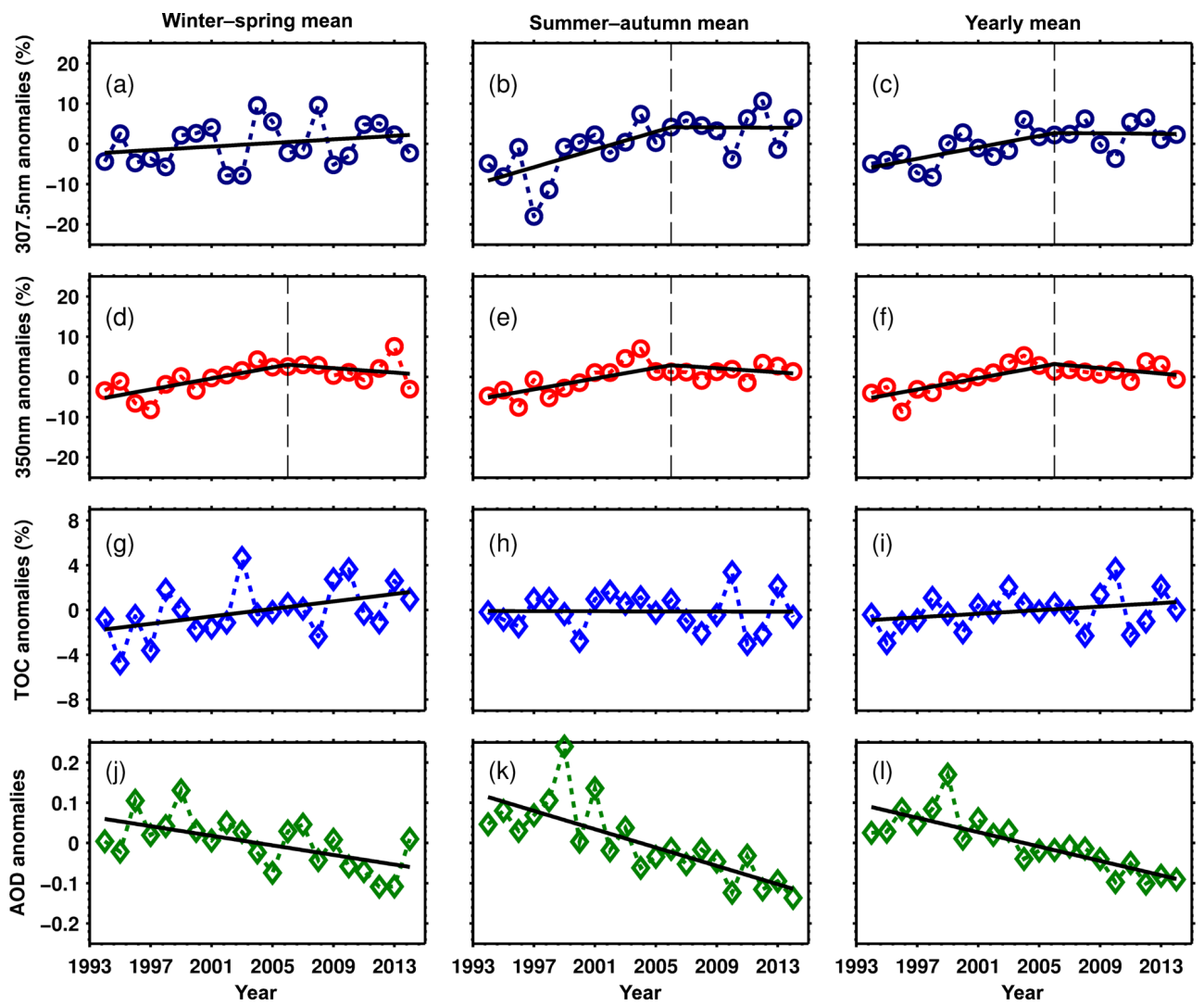

Figure 5. Yearly mean anomalies and corresponding trends for clear-sky irradiance at $307.5 \mathrm{~nm}(\mathbf{a}, \mathbf{b}, \mathbf{c})$ and $350 \mathrm{~nm}(\mathbf{d}, \mathbf{e}, \mathbf{f})$, TOC (g, h, i) and AOD at $320 \mathrm{~nm}(\mathbf{j}, \mathbf{k}, \mathbf{l})$ for December-May (left panels), June-November (middle panels) and for the entire year (right panels). A piece-wise trend consisting of two linear trends has been drawn when a statistically significant turning point has been detected; otherwise a linear trend for the entire period has been drawn.

$307.5 \mathrm{~nm}$ in 2010 is still higher than mean levels in the period 1994-1998, mainly due to the very high levels of aerosols in the atmosphere in the mid-1990s. As the AOD decreases throughout the years, the anti-correlation between the shortterm variability of the TOC and the UV irradiance becomes clearer. Finally, it is noteworthy that while the mean value of AOD for 2014 in the period summer-autumn is the lowest recorded since 1994, the corresponding value for the period winter-spring is the highest of the last 7 years. These very high AOD values are probably due to the increased biomassburning aerosols arising from a shift in the type of fuel owing to the economic crisis in Greece after 2009 (Saffari et al., 2013). As a consequence of the increased aerosols, the levels of irradiance at $350 \mathrm{~nm}$ for winter-spring 2014 are the lowest recorded during the last decade.

Since this section aimed at attributing the short- and longterm variability of the UV irradiance to the corresponding variability of TOC and AOD, the analysis was restricted to clear-sky data. Although not shown here, a similar analysis has been performed for the irradiance under all-sky conditions and a statistically significant turning point in 2006 has also been detected in the trends of yearly mean irradi- ance for 307.5 and $350 \mathrm{~nm}$. As already discussed, changes in cloudiness do not have an important impact on the long-term changes of the UV irradiance at Thessaloniki but are the main driver of the short-term variations in the all-sky data set.

\section{Summary and conclusions}

In the present study, spectral UV irradiance measurements from 1994 to 2014 at Thessaloniki, Greece, have been used to investigate the short- and long-term variability of UV irradiance at specific wavelengths, affected differently by total ozone, aerosols and clouds. Although data are available since 1990 the analysis was restricted to the period 1994-2014 to avoid interferences in the trends from the volcanic aerosols injected into the stratosphere by the eruption of Mt Pinatubo in 1991. Additionally, the parallel measurements from two co-located Brewer spectrophotometers after 1993 increase the confidence in the accuracy of the spectral measurements. Trends of clear-sky and all-sky UV irradiance at 307.5 and $324 \mathrm{~nm}$ were derived for the period 1994-2014 from both B005 and B086 for SZAs from 30 to $70^{\circ}$. The difference be- 
tween the trends from the two instruments was found to be smaller than their $1 \sigma$ uncertainty boundaries.

According to the results, the annual mean UV irradiance has increased during the last two decades. The increasing trends are similar for both clear-sky and all-sky data and are higher at shorter wavelengths and higher SZAs. The calculated trends range between 2 and $6 \%$ per decade, and for clear-skies are statistically significant for most SZAs. For all-skies, most of the irradiance trends are not statistically significant.

The impact of changes in TOC, aerosols and clouds on the changes in UV irradiance is different for different seasons. The negative trends in AOD, which are stronger in summer, lead to positive trends in UV irradiance at longer wavelengths (e.g. at 324 and $350 \mathrm{~nm}$ ). For shorter wavelengths changes in TOC are also important. Thus, the effect of the small negative trend in AOD in winter is fully counteracted by the positive trend in TOC, resulting in a decreasing trend in clear-sky irradiance at $307.5 \mathrm{~nm}$. Changes in clouds have a negligible effect on the trend of irradiance for winter and spring. The enhancement of the attenuation of irradiance by clouds in autumn is balanced by the reduced attenuation in summer, leading to similar changes in the annual means of clear-sky and all-sky irradiance. It is important to notice that the strongest changes in UV irradiance were found for summer when humans are more exposed to the Sun compared to the other seasons.

Moreover, it is shown that the period 1994-2014 can be divided in two sub-periods: during the first period (1994-2006) the annual mean UV irradiance is increasing fast while during the second period (2006-2014) the UV irradiance is relatively stable at $307.5 \mathrm{~nm}$ and is slightly decreasing at $350 \mathrm{~nm}$. The long-term variability of UV irradiance for both short and long wavelengths is mainly driven by the changes in aerosols. The short-term variability of the clear-sky irradiance at $307.5 \mathrm{~nm}$ is mainly driven by the short-term variability of TOC. The effect of the TOC changes on the year-to-year variability of UV irradiance becomes clearer when AOD decreases. The short-term changes in irradiance at $350 \mathrm{~nm}$ cannot be fully explained by the short-term changes in AOD, as the absorption efficiency of aerosols may also change with time.

Edited by: S. Kazadzis

\section{References}

Amiridis, V., Balis, D. S., Kazadzis, S., Bais, A., Giannakaki, E., Papayannis, A., and Zerefos, C.: Four-year aerosol observations with a Raman lidar at Thessaloniki, Greece, in the framework of European Aerosol Research Lidar Network (EARLINET), J. Geophys. Res.-Atmos., 110, D21203, doi:10.1029/2005jd006190, 2005.
Anderson, G. P., Clough, S., Kneizys, F., Chetwynd, J., and Shettle, E. P.: AFGL atmospheric constituent profiles $(0-120 \mathrm{~km})$, Tech. Rep. TR-86-0110, AFGL, DTIC Document, 1986.

Antón, M., Serrano, A., Cancillo, M. L., GarcíA, J. A., and Madronich, S.: Application of an analytical formula for UV Index reconstructions for two locations in Southwestern Spain, Tellus B, 63, 1052-1058, 2011.

Arola, A., Lakkala, K., Bais, A., Kaurola, J., Meleti, C., and Taalas, P.: Factors affecting short- and long-term changes of spectral UV irradiance at two European stations, J. Geophys. Res.-Atmos., 108, 4549, doi:10.1029/2003jd003447, 2003.

Asta, J., Pål, B., Arne, D., Stefan, A.-E., Jörg, R., Kristin, M., Michael, F. H., William, B. G., and Johan, M.: Solar radiation and human health, Rep. Prog. Phys., 74, 066701, doi:10.1088/00344885/74/6/066701, 2011.

Bais, A. F., Zerefos, C. S., Ziomas, I. C., Zoumakis, N., Mantis, H. T., Hofmann, D. J., and Fiocco, G.: Decreases in the Ozone and the $\mathrm{SO}_{2}$ Columns Following the Appearence of the El Chichon Aerosol Cloud at Midlatitude, in: Atmospheric Ozone, edited by: Zerefos, C. S. and Ghazi, A., Springer Netherlands, 1985.

Bais, A. F., Zerefos, C. S., Meleti, C., Ziomas, I. C., and Tourpali, K.: Spectral measurements of solar UVB radiation and its relations to total ozone, $\mathrm{SO}_{2}$, and clouds, J. Geophys. Res.-Atmos., 98, 5199-5204, 1993.

Bais, A. F., Zerefos, C. S., and McElroy, C. T.: Solar UVB measurements with the double- and single-monochromator Brewer ozone spectrophotometers, Geophys. Res. Lett., 23, 833-836, 1996.

Bais, A. F., Gardiner, B. G., Slaper, H., Blumthaler, M., Bernhard, G., McKenzie, R., Webb, A. R., Seckmeyer, G., Kjeldstad, B., Koskela, T., Kirsch, P. J., Gröbner, J., Kerr, J. B., Kazadzis, S., Leszczynski, K., Wardle, D., Josefsson, W., Brogniez, C., Gillotay, D., Reinen, H., Weihs, P., Svenoe, T., Eriksen, P., Kuik, F., and Redondas, A.: SUSPEN intercomparison of ultraviolet spectroradiometers, J. Geophys. Res.-Atmos., 106, 1250912525, 2001.

Bais, A. F., Kazantzidis, A., Kazadzis, S., Balis, D. S., Zerefos, C. S., and Meleti, C.: Deriving an effective aerosol single scattering albedo from spectral surface UV irradiance measurements, Atmos. Environ., 39, 1093-1102, 2005.

Bais, A. F., Tourpali, K., Kazantzidis, A., Akiyoshi, H., Bekki, S., Braesicke, P., Chipperfield, M. P., Dameris, M., Eyring, V., Garny, H., Iachetti, D., Jöckel, P., Kubin, A., Langematz, U., Mancini, E., Michou, M., Morgenstern, O., Nakamura, T., Newman, P. A., Pitari, G., Plummer, D. A., Rozanov, E., Shepherd, T. G., Shibata, K., Tian, W., and Yamashita, Y.: Projections of UV radiation changes in the 21st century: impact of ozone recovery and cloud effects, Atmos. Chem. Phys., 11, 7533-7545, doi:10.5194/acp-11-7533-2011, 2011.

Bais, A. F., Drosoglou, T., Meleti, C., Tourpali, K., and Kouremeti, N.: Changes in surface shortwave solar irradiance from 1993 to 2011 at Thessaloniki (Greece), Int. J. Climatol., 33, 2871-2876, 2013.

Bais, A. F., McKenzie, R. L., Bernhard, G., Aucamp, P. J., Ilyas, M., Madronich, S., and Tourpali, K.: Ozone depletion and climate change: impacts on UV radiation, Photochem. Photobio. S., 14, 19-52, doi:10.1039/c4pp90032d, 2015.

Ballare, C. L., Caldwell, M. M., Flint, S. D., Robinson, S. A., and Bornman, J. F.: Effects of solar ultraviolet radiation on terrestrial 
ecosystems. Patterns, mechanisms, and interactions with climate change, Photochem. Photobio. S., 10, 226-241, 2011.

Bernhard, G.: Trends of solar ultraviolet irradiance at Barrow, Alaska, and the effect of measurement uncertainties on trend detection, Atmos. Chem. Phys., 11, 13029-13045, doi:10.5194/acp-11-13029-2011, 2011.

Bernhard, G., Booth, C. R., Ehramjian, J. C., Stone, R., and Dutton, E. G.: Ultraviolet and visible radiation at Barrow, Alaska: Climatology and influencing factors on the basis of version 2 National Science Foundation network data, J. Geophys. Res.-Atmos., 112, D09101, doi:10.1029/2006jd007865, 2007.

Brewer, A. W.: A replacement for the Dobson spectrophotometer?, PAGEOPH, 106-108, 919-927, 1973.

Burkey, J.: A non-parametric monotonic trend test computing Mann-Kendall Tau, Tau-b, and Sens Slope written in MathworksMATLAB implemented using matrix rotations, King County, Department of Natural Resources and Parks, Science and Technical Services section, Seattle, Washington, USA, 2006.

Cordero, R. R., Seckmeyer, G., Damiani, A., Labbe, F., and Laroze, D.: Monte Carlo-based uncertainties of surface UV estimates from models and from spectroradiometers, Metrologia, 50, L1L5, doi:10.1088/0026-1394/50/5/L1, 2013.

Damiani, A., Cordero, R. R., Cabrera, S., Laurenza, M., and Rafanelli, C.: Cloud cover and UV index estimates in Chile from satellite-derived and ground-based data, Atmos. Res., 138, 139$151,2014$.

De Bock, V., De Backer, H., Van Malderen, R., Mangold, A., and Delcloo, A.: Relations between erythemal UV dose, global solar radiation, total ozone column and aerosol optical depth at Uccle, Belgium, Atmos. Chem. Phys., 14, 12251-12270, doi:10.5194/acp-14-12251-2014, 2014.

Egorova, T., Rozanov, E., Gröbner, J., Hauser, M., and Schmutz, W.: Montreal Protocol Benefits simulated with CCM SOCOL, Atmos. Chem. Phys., 13, 3811-3823, doi:10.5194/acp-13-38112013, 2013.

Eleftheratos, K., Kazadzis, S., Zerefos, C. S., Tourpali, K., Meleti, C., Balis, D., Zyrichidou, I., Lakkala, K., Feister, U., Koskela, T., Heikkilä, A., and Karhu, J. M.: Ozone and Spectroradiometric UV Changes in the Past 20 Years over High Latitudes, Atmos. Ocean, 53, 117-125, doi:10.1080/07055900.2014.919897, 2014.

Farman, J. C., Gardiner, B. G., and Shanklin, J. D.: Large losses of total ozone in Antarctica reveal seasonal $\mathrm{ClO}_{x} / \mathrm{NO}_{x}$ interaction, Nature, 315, 207-210, 1985.

Fioletov, V. E., Kerr, J. B., Hare, E. W., Labow, G. J., and McPeters, R. D.: An assessment of the world ground-based total ozone network performance from the comparison with satellite data, J. Geophys. Res.-Atmos., 104, 1737-1747, 1999.

Fioletov, V. E., Kimlin, M. G., Krotkov, N., McArthur, L. J. B., Kerr, J. B., Wardle, D. I., Herman, J. R., Meltzer, R., Mathews, T. W., and Kaurola, J.: UV index climatology over the United States and Canada from ground-based and satellite estimates, J. Geophys. Res.-Atmos., 109, D22308, doi:10.1029/2004jd004820, 2004.

Fitzka, M., Simic, S., and Hadzimustafic, J.: Trends in spectral UV radiation from long-term measurements at Hoher Sonnblick, Austria, Theor. Appl. Climatol., 110, 585-593, 2012.

Fragkos, K., Bais, A. F., Fountoulakis, I., Balis, D., Tourpali, K., Meleti, C., and Zanis, P.: Extreme total column ozone events and effects on UV solar radiation at Thessaloniki, Greece, Theor. Appl. Climatol., 1-13, doi:10.1007/s00704-015-1562-3, 2015.
Garane, K., Bais, A. F., Kazadzis, S., Kazantzidis, A., and Meleti, C.: Monitoring of UV spectral irradiance at Thessaloniki (19902005): data re-evaluation and quality control, Ann. Geophys., 24, 3215-3228, 2006.

García, R. D., Cachorro, V. E., Cuevas, E., Toledano, C., Redondas, A., Blumthaler, M., and Benounna, Y.: Comparison of measured and modelled spectral UV irradiance at Izaña high mountain station: estimation of the underlying effective albedo, Int. J. Climatol., 36, 377-388, doi:10.1002/joc.4355, 2015.

Glandorf, M., Arola, A., Bais, A., and Seckmeyer, G.: Possibilities to detect trends in spectral UV irradiance, Theor. Appl. Climatol., 81, 33-44, 2005.

Gröbner, J., Blumthaler, M., Kazadzis, S., Bais, A., Webb, A., Schreder, J., Seckmeyer, G., and Rembges, D.: Quality assurance of spectral solar UV measurements: results from $25 \mathrm{UV}$ monitoring sites in Europe, 2002 to 2004, Metrologia, 43, S66-S71, doi:10.1088/0026-1394/43/2/S14, 2006.

Gröbner, J. and Meleti, C.: Aerosol optical depth in the UVB and visible wavelength range from Brewer spectrophotometer direct irradiance measurements: 1991-2002, J. Geophys. Res.-Atmos., 109, D09202, doi:10.1029/2003jd004409, 2004.

Häder, D. P., Helbling, E. W., Williamson, C. E., and Worrest, R. C.: Effects of UV radiation on aquatic ecosystems and interactions with climate change, Photochem. Photobio. S., 10, 242260, 2011.

Häder, D.-P., Williamson, C. E., Wangberg, S.-A., Rautio, M., Rose, K. C., Gao, K., Helbling, E. W., Sinha, R. P., and Worrest, R.: Effects of UV radiation on aquatic ecosystems and interactions with other environmental factors, Photochem. Photobio. S., 14, 108-126, doi:10.1039/c4pp90035a, 2015.

Hegglin, M. I. and Shepherd, T. G.: Large climate-induced changes in ultraviolet index and stratosphere-to-troposphere ozone flux, Nat. Geosci., 2, 687-691, 2009.

Hofmann, D. J., Oltmans, S. J., Komhyr, W. D., Harris, J. M., Lathrop, J. A., Langford, A. O., Deshler, T., Johnson, B. J., Torres, A., and Matthews, W. A.: ozone loss in the lower stratosphere over the United States in 1992-1993: Evidence for heterogeneous chemistry on the Pinatubo aerosol, Geophys. Res. Lett., 21, 65-68, 1994.

Ialongo, I., Buchard, V., Brogniez, C., Casale, G. R., and Siani, A. M.: Aerosol Single Scattering Albedo retrieval in the UV range: an application to OMI satellite validation, Atmos. Chem. Phys., 10, 331-340, doi:10.5194/acp-10-331-2010, 2010.

IPCC: Climate Change 2013: The Physical Science Basis. Contribution of Working Group I to the Fifth Assessment Report of the Intergovernmental Panel on Climate Change Cambridge University Press, Cambridge, United Kingdom and New York, NY, USA, 1535 pp., 2013.

Karppinen, T., Redondas, A., García, R. D., Lakkala, K., McElroy, C. T., and Kyrö, E.: Compensating for the Effects of Stray Light in Single-Monochromator Brewer Spectrophotometer Ozone Retrieval, Atmos. Ocean, 53, 66-73, doi:10.1080/07055900.2013.871499, 2014.

Kazadzis, S., Bais, A., Amiridis, V., Balis, D., Meleti, C., Kouremeti, N., Zerefos, C. S., Rapsomanikis, S., Petrakakis, M., Kelesis, A., Tzoumaka, P., and Kelektsoglou, K.: Nine years of UV aerosol optical depth measurements at Thessaloniki, Greece, Atmos. Chem. Phys., 7, 2091-2101, doi:10.5194/acp-7-20912007, 2007. 
Kazadzis, S., Bais, A., Arola, A., Krotkov, N., Kouremeti, N., and Meleti, C.: Ozone Monitoring Instrument spectral UV irradiance products: comparison with ground based measurements at an urban environment, Atmos. Chem. Phys., 9, 585-594, doi:10.5194/acp-9-585-2009, 2009.

Kazantzidis, A., Bais, A., Garane, K., Kazadzis, S., and Meleti, C.: Estimation of UV irradiance from ancillary data and comparison with measurements at Thessaloniki, Greece $\left(40.5^{\circ} \mathrm{N}, 23^{\circ} \mathrm{E}\right)$, 6362, 636228, doi:10.1117/12.689813, 2006.

Kazantzidis, A., Bais, A. F., Zempila, M. M., Kazadzis, S., den Outer, P. N., Koskela, T., and Slaper, H.: Calculations of the human vitamin D exposure from UV spectral measurements at three European stations, Photochem. Photobio. S., 8, 45-51, 2009.

Kazantzidis, A., Smedley, A., Kift, R., Rimmer, J., Berry, J., Rhodes, L. E., and Webb, A.: A modeling approach to determine how much UV radiation is available across the UK and Ireland for health risk and benefit studies, Photochem. Photobio. S., 14, 1073-1081, doi:10.1039/c5pp00008d, 2015.

Kerr, J. B. and Fioletov, V. E.: Surface ultraviolet radiation, Atmos. Ocean, 46, 159-184, 2008.

Kerr, J. B. and McElroy, C. T.: Evidence for Large Upward Trends of Ultraviolet-B Radiation Linked to Ozone Depletion, Science, 262, 1032-1034, 1993.

Kerr, J. B., McElroy, C. T., and Olafson, R. A.: Measurements of ozone with the Brewer spectrophotometer, Quadrennial International Ozone Symposium, Natl. Cent. for Atmos. Res., Boulder, Colorado, 74-79, 1981.

Kerr, J. B., Evans, W. F. J., and Asbridge, I. A.: Recalibration of Dobson Field Spectrophotometers with a Travelling Brewer Spectrophotometer Standard, in: Atmospheric Ozone, edited by: Zerefos, C. S. and Ghazi, A., Springer Netherlands, 1985.

Koukouli, M. E., Balis, D. S., Amiridis, V., Kazadzis, S., Bais, A., Nickovic, S., and Torres, O.: Aerosol variability over Thessaloniki using ground based remote sensing observations and the TOMS aerosol index, Atmos. Environ., 40, 5367-5378, 2006.

Kreuter, A., Buras, R., Mayer, B., Webb, A., Kift, R., Bais, A., Kouremeti, N., and Blumthaler, M.: Solar irradiance in the heterogeneous albedo environment of the Arctic coast: measurements and a 3-D model study, Atmos. Chem. Phys., 14, 59896002, doi:10.5194/acp-14-5989-2014, 2014.

Kuttippurath, J., Lefèvre, F., Pommereau, J.-P., Roscoe, H. K., Goutail, F., Pazmiño, A., and Shanklin, J. D.: Antarctic ozone loss in 1979-2010: first sign of ozone recovery, Atmos. Chem. Phys., 13, 1625-1635, doi:10.5194/acp-13-1625-2013, 2013.

Lakkala, K., Arola, A., Heikkilä, A., Kaurola, J., Koskela, T., Kyrö, E., Lindfors, A., Meinander, O., Tanskanen, A., Gröbner, J., and Hülsen, G.: Quality assurance of the Brewer spectral UV measurements in Finland, Atmos. Chem. Phys., 8, 3369-3383, doi:10.5194/acp-8-3369-2008, 2008.

Li, Z., Wang, P., and Cihlar, J.: A simple and efficient method for retrieving surface UV radiation dose rate from satellite, J. Geophys. Res.-Atmos., 105, 5027-5036, 2000.

Lucas, R. M., Norval, M., Neale, R. E., Young, A. R., de Gruijl, F. R., Takizawa, Y., and van der Leun, J. C.: The consequences for human health of stratospheric ozone depletion in association with other environmental factors, Photochem. Photobio. S., 14, 53-87, doi:10.1039/c4pp90033b, 2015.

Mäder, J. A., Staehelin, J., Peter, T., Brunner, D., Rieder, H. E., and Stahel, W. A.: Evidence for the effectiveness of the Mon- treal Protocol to protect the ozone layer, Atmos. Chem. Phys. 10, 12161-12171, doi:10.5194/acp-10-12161-2010, 2010.

Madronich, S., McKenzie, R. L., and Caldwell, M. M.: Changes in ultraviolet radiation reaching the earth's surface, Ambio, 24, 143-152, 1995.

Madronich, S., McKenzie, R. L., Björn, L. O., and Caldwell, M. M.: Changes in biologically active ultraviolet radiation reaching the Earth's surface, J. Photochem. Photobiol. B, 46, 5-19, 1998.

Madronich, S., Shao, M., Wilson, S. R., Solomon, K. R., Longstreth, J. D., and Tang, X. Y.: Changes in air quality and tropospheric composition due to depletion of stratospheric ozone and interactions with changing climate: implications for human and environmental health, Photochem. Photobio. S., 14, 149169, doi:10.1039/c4pp90037e, 2015.

Mayer, B. and Kylling, A.: Technical note: The libRadtran software package for radiative transfer calculations - description and examples of use, Atmos. Chem. Phys., 5, 1855-1877, doi:10.5194/acp-5-1855-2005, 2005.

McLinden, C. A. and Fioletov, V.: Quantifying stratospheric ozone trends: Complications due to stratospheric cooling, Geophys. Res. Lett., 38, L03808, doi:10.1029/2010GL046012, 2011.

Meinander, O., Wuttke, S., Seckmeyer, G., Kazadzis, S., Lindfors, A., and Kyrö, E.: Solar zenith angle asymmetry cases in polar snow UV albedo, Geophysica, 45, 183-198, 2009.

Meleti, C. and Cappellani, F.: Measurements of aerosol optical depth at Ispra: Analysis of the correlation with UV-B, UV-A, and total solar irradiance, J. Geophys. Res.-Atmos., 105, 4971-4978, 2000.

Meleti, C., Bais, A. F., Kazadzis, S., Kouremeti, N., Garane, K., and Zerefos, C.: Factors affecting solar ultraviolet irradiance measured since 1990 at Thessaloniki, Greece, Int. J. Remote Sens., 30, 4167-4179, 2009.

Meleti, C., Fragkos, K., Bais, A. F., Tourpali, K., Balis, D., and Zerefos, C. S.: Thirty years of total ozone measurements at Thessaloniki with a MKII Brewer spectrophotometer, Quadrennial Ozone Symposium 2012, Toronto, 2012.

Morgenstern, O., Braesicke, P., Hurwitz, M. M., O’Connor, F. M., Bushell, A. C., Johnson, C. E., and Pyle, J. A.: The World Avoided by the Montreal Protocol, Geophys. Res. Lett., 35, L16811, doi:10.1029/2008g1034590, 2008.

Newchurch, M. J., Yang, E.-S., Cunnold, D. M., Reinsel, G. C., Zawodny, J. M., and Russell, J. M.: Evidence for slowdown in stratospheric ozone loss: First stage of ozone recovery, J. Geophys. Res.-Atmos., 108, 4507, doi:10.1029/2003jd003471, 2003.

Newman, P. A. and McKenzie, R.: UV impacts avoided by the Montreal Protocol, Photochem. Photobio. S., 10, 1152-1160, 2011.

Nikitidou, E., Kazantzidis, A., De Bock, V., and De Backer, H.: The aerosol forcing efficiency in the UV region and the estimation of single scattering albedo at a typical West European site, Atmos. Environ., 69, 313-320, 2013.

Randel, W. J., Wu, F., Russell, J. M., Waters, J. W., and Froidevaux, L.: Ozone and temperature changes in the stratosphere following the eruption of Mount Pinatubo, J. Geophys. Res.-Atmos., 100, 16753-16764, 1995.

Román, R., Bilbao, J., and de Miguel, A.: Erythemal ultraviolet irradiation trends in the Iberian Peninsula from 1950 to 2011, Atmos. Chem. Phys., 15, 375-391, doi:10.5194/acp-15-375-2015, 2015. 
Saffari, A., Daher, N., Samara, C., Voutsa, D., Kouras, A., Manoli, E., Karagkiozidou, O., Vlachokostas, C., Moussiopoulos, N., Shafer, M. M., Schauer, J. J., and Sioutas, C.: Increased Biomass Burning Due to the Economic Crisis in Greece and Its Adverse Impact on Wintertime Air Quality in Thessaloniki, Environ. Sci. Technol., 47, 13313-13320, 2013.

Schwander, H., Koepke, P., and Ruggaber, A.: Uncertainties in modeled UV irradiances due to limited accuracy and availability of input data, J. Geophys. Res.-Atmos., 102, 9419-9429, 1997.

Shettle, E. P.: Models of aerosols, clouds and precipitation for atmospheric propagation studies, in: AGARD, Atmospheric Propagation in the UV, Visible, IR, and MM-Wave Region and Related Systems Aspects 14 pp., 1989.

Smedley, A. R. D., Rimmer, J. S., Moore, D., Toumi, R., and Webb, A. R.: Total ozone and surface UV trends in the United Kingdom: 1979-2008, Int. J. Climatol., 32, 338-346, 2012.

Solomon, S., Garcia, R. R., Rowland, F. S., and Wuebbles, D. J.: On the depletion of Antarctic ozone, Nature, 321, 755-758, 1986.

Steinbrecht, W., Köhler, U., Claude, H., Weber, M., Burrows, J. P., and van der A, R. J.: Very high ozone columns at northern mid-latitudes in 2010, Geophys. Res. Lett., 38, 1944-8007, doi:10.1029/2010GL046634, 2011.

Takemura, T., Nakajima, T., Dubovik, O., Holben, B. N., and Kinne, S.: Single-Scattering Albedo and Radiative Forcing of Various Aerosol Species with a Global Three-Dimensional Model, J. Climate, 15, 333-352, 2002.

Tourpali, K., Bais, A. F., Kazantzidis, A., Zerefos, C. S., Akiyoshi, H., Austin, J., Brühl, C., Butchart, N., Chipperfield, M. P., Dameris, M., Deushi, M., Eyring, V., Giorgetta, M. A., Kinnison, D. E., Mancini, E., Marsh, D. R., Nagashima, T., Pitari, G., Plummer, D. A., Rozanov, E., Shibata, K., and Tian, W.: Clear sky UV simulations for the 21 st century based on ozone and temperature projections from Chemistry-Climate Models, Atmos. Chem. Phys., 9, 1165-1172, doi:10.5194/acp-9-1165-2009, 2009.

Turnock, S. T., Spracklen, D. V., Carslaw, K. S., Mann, G. W., Woodhouse, M. T., Forster, P. M., Haywood, J., Johnson, C. E., Dalvi, M., Bellouin, N., and Sanchez-Lorenzo, A.: Modelled and observed changes in aerosols and surface solar radiation over Europe between 1960 and 2009, Atmos. Chem. Phys., 15, 94779500, doi:10.5194/acp-15-9477-2015, 2015.

UNEP: Environmental effects of ozone depletion and its interaction with climate change: 2010 assessment, report, 278 pp., Nairobi, Kenya, 2010.

van Dijk, A., Slaper, H., den Outer, P. N., Morgenstern, O., Braesicke, P., Pyle, J. A., Garny, H., Stenke, A., Dameris, M., Kazantzidis, A., Tourpali, K., and Bais, A. F.: Skin Cancer Risks Avoided by the Montreal Protocol - Worldwide Modeling Integrating Coupled Climate-Chemistry Models with a Risk Model for UV, Photochem. Photobiol., 89, 234-246, 2013.
Walker, D.: Cloud effects on erythemal UV radiation in a complex topography, Diss., Eidgenössische Technische Hochschule ETH Zürich, No. 18415, doi:10.3929/ethz-a-005914035, 2009.

Watanabe, S., Sudo, K., Nagashima, T., Takemura, T., Kawase, H., and Nozawa, T.: Future projections of surface UV-B in a changing climate, J. Geophys. Res.-Atmos., 116, D16118, doi:10.1029/2011jd015749, 2011.

Weatherhead, E. C., Reinsel, G. C., Tiao, G. C., Meng, X.-L., Choi, D., Cheang, W.-K., Keller, T., DeLuisi, J., Wuebbles, D. J., Kerr, J. B., Miller, A. J., Oltmans, S. J., and Frederick, J. E.: Factors affecting the detection of trends: Statistical considerations and applications to environmental data, J. Geophys. Res.-Atmos., 103, 17149-17161, 1998.

Webb, A. R., Kift, R., Durkin, M. T., O’Brien, S. J., Vail, A., Berry, J. L., and Rhodes, L. E.: The role of sunlight exposure in determining the vitamin D status of the U.K. white adult population, Brit. J. Dermatol., 163, 1050-1055, 2010.

Weihs, P. and Webb, A. R.: Accuracy of spectral UV model calculations: 1. Consideration of uncertainties in input parameters, J. Geophys. Res.-Atmos., 102, 1541-1550, 1997.

Williamson, C. E., Zepp, R. G., Lucas, R. M., Madronich, S., Austin, A. T., Ballare, C. L., Norval, M., Sulzberger, B., Bais, A. F., McKenzie, R. L., Robinson, S. A., Häder, D.-P., Paul, N. D., and Bornman, J. F.: Solar ultraviolet radiation in a changing climate, Nature Clim. Change, 4, 434-441, 2014.

WMO: Scientific assessment of ozone depletion: 2006, Global Ozone Res. Monit. Proj. Rep. 50, 572 pp., 2007.

Yang, E.-S., Cunnold, D. M., Salawitch, R. J., McCormick, M. P., Russell, J., Zawodny, J. M., Oltmans, S., and Newchurch, M. J.: Attribution of recovery in lower-stratospheric ozone, J. Geophys Res.-Atmos., 111, D17309, doi:10.1029/2005jd006371, 2006.

Zerefos, C.: Evidence of the El Chichón stratospheric volcanic cloud in Northern Greece, Geofísica Internacional, 23, 299-304, 1984.

Zerefos, C. S.: Long-term ozone and UV variations at Thessaloniki, Greece, Physics and Chemistry of the Earth, Parts A/B/C, 27, 455-460, 2002.

Zerefos, C. S., Tourpali, K., Eleftheratos, K., Kazadzis, S., Meleti, C., Feister, U., Koskela, T., and Heikkilä, A.: Evidence of a possible turning point in solar UV-B over Canada, Europe and Japan, Atmos. Chem. Phys., 12, 2469-2477, doi:10.5194/acp-12-24692012, 2012. 